Original Article

\title{
Effectiveness of Video-Assisted Teaching on Breast Crawl among nursing students of selected Nursing Institutes at M angalore.
}

\section{Soumya George ${ }^{1}$, Shynee Paul ${ }^{2}$}

${ }^{1}$ Senior Lecturer, College of Nursing, ACME, Pariyarum, Kerala, ${ }^{2}$ Professor, Department of Obstetrics \& Gynaecological Nursing, Nitte Usha Institute of Nursing Sciences, Nitte University, M angalore, Karnataka, India.

*Corresponding Author : Shynee Paul, Professor, Department of Obstetrics \&Gynaecological Nursing, Nitte Usha Institute of Nursing Sciences, NitteUniversity, M angalore, Karnataka. M obile : +919886804873 E-mail : shinypl@yahoo.com

$\begin{array}{ll}\text { Received } & : 04.06 .2016 \\ \text { Review Completed } & : 08.08 .2017 \\ \text { Accepted } & : 10.08 .2017\end{array}$

Keywords : Effectiveness Breast Crawl, Video Assisted Teaching Programme, Nursing students

\begin{tabular}{|c|}
\hline Access this article online \\
\hline Quick Response Code \\
\hline
\end{tabular}

\begin{abstract}
Background: UNICEF, WHO and WABA, along with the scientific community, strongly recommend initiating breastfeeding within a half-hour of birth. Evidence shows that early initiation can prevent $22 \%$ of all deaths among babies below one month in developing countries. Every newborn, when placed on her mother's abdomen, soon after birth, has the ability to find her mother's breast all on her own and to decide when to take the first breastfeed. This is called the 'Breast Crawl'.
\end{abstract}

Materials and Methods: An experimental approach with one group pre-test post test design was used for the study. The sample comprises of 60 nursing students who meets inclusion criteria were selected using Random sampling technique.pre test was conducted with structured knowledge questionnaire, followed by administered the video assisted teaching programme on breast crawl. Post test was conducted after 7 days of intervention by using same tool

Result: The collected data were analyzed using descriptive $\&$ inferential statistics The findings of the data showed that the mean post test knowledge of subjects were significantly higher than their mean pre test knowledge scores after the administration of video assisted teaching. (' $\mathrm{t}$ ' value 14.93, $P>0.05)$. No association wasfound

Conclusion: A baby is born with many instinctive abilities which enable her to perform the Breast Crawl. Hence video assisted teaching is very essential and beneficial in nursing field to educate nursing students.

\section{Introduction}

UNICEF and its partners are highlighting a natural occurrence called the 'breast crawl', which can benefit mothers and newborns around the world. . A baby is born with many instinctive abilities which enable her to perform the Breast Crawl. The breast crawl is the first skin-to-skin contact the baby has with the mother right after the birth. All newborns, when placed on the mother's abdomen soon after birth, have the ability to crawl to their mother's breast and begin feeding on their own Evidence shows that early initiation can prevent $22 \%$ of all deaths among babies below one month in the developing countries. The benefits of using video in education includes providing a sensory experience that allows concepts and ideas to actually become an experience and come to life as students are guided through each adventure.

\section{Objectives}

- To assess the existing knowledge on breast crawl among nursingstudents.

- To determine the effectiveness of video assisted teaching programme on breast crawl.

- To determine the association between knowledge on breast crawland selected demographic variables

\section{Materials \& methods}

- Research Approach: Quantitative (Experimental).

- Research Design: One group pre-test and post-test design (pre experimental).

- Sample Size: 60 nursing students who met the inclusion criteria were selected as sample.

- Sampling Technique: Random sampling. 
- Data collection instrument: Structured knowledge questionnaire, Video-Assisted Teaching, Demographic Performa.

\section{Result}

Distribution of samples according to demographic characteristics:

$n=60$

\begin{tabular}{|c|c|c|c|}
\hline & Sample Characteristics & Frequency & Percentage (\%) \\
\hline \multirow[t]{3}{*}{1.} & Gender & & \\
\hline & Male & 5 & 8 \\
\hline & Female & 55 & 92 \\
\hline \multirow[t]{4}{*}{2.} & Age in years & & \\
\hline & $17-20$ & 0 & 0 \\
\hline & $21-24$ & 60 & 100 \\
\hline & $25-28$ & 0 & 0 \\
\hline \multirow[t]{3}{*}{3.} & Education & & \\
\hline & B. Sc nursing & 30 & 50 \\
\hline & GNM & 30 & 50 \\
\hline
\end{tabular}

4. Exposure to educational programme on breast crawl.

\begin{tabular}{|c|c|c|c|}
\hline & $\begin{array}{l}\text { Yes } \\
\text { No }\end{array}$ & $\begin{array}{c}0 \\
60\end{array}$ & $\begin{array}{c}0 \\
100\end{array}$ \\
\hline \multirow[t]{4}{*}{5.} & \multicolumn{2}{|c|}{ Clinical experience in months } & \\
\hline & 0-1 month & 0 & 0 \\
\hline & 1-2 months & 30 & 50 \\
\hline & $2-3$ months & 30 & 50 \\
\hline
\end{tabular}

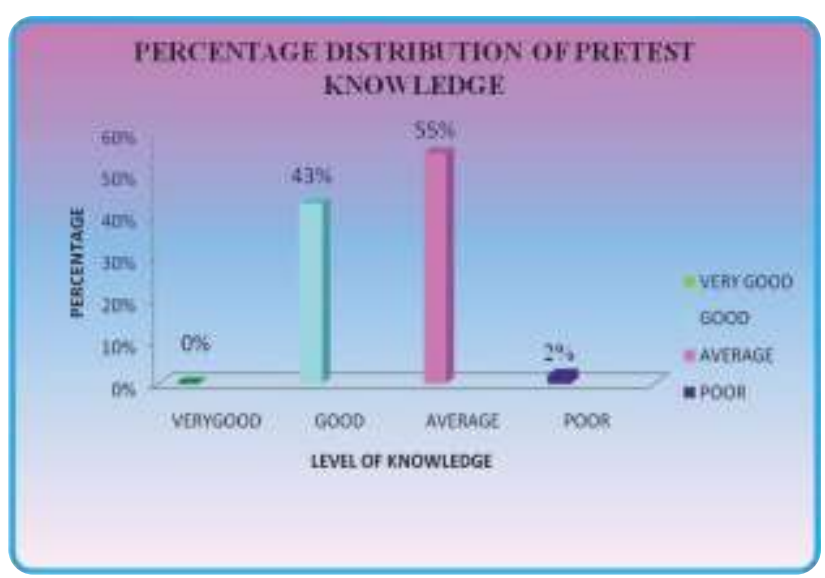

SCORE

\begin{tabular}{|l|c|c|}
\hline Score range & Frequency & Percentage (\%) \\
\hline $\begin{array}{l}\text { Very good } \\
(25-32)\end{array}$ & 0 & 0 \\
\hline $\begin{array}{l}\text { Good } \\
(17-24)\end{array}$ & 26 & 43 \\
\hline $\begin{array}{l}\text { Average } \\
(9-16)\end{array}$ & 33 & 55 \\
\hline $\begin{array}{l}\text { Poor } \\
(0-8)\end{array}$ & 1 & 2 \\
\hline
\end{tabular}

\section{Effectiveness of video assisted teaching on knowledge of Breast Crawl}

In order to determine the effectiveness of video assisted teaching, the significance of difference between the mean of pre-test and post-test knowledge scores of sample was computed using a Paired 't' test.

Mean, Mean Difference, Standard error of Difference, and't' value of pre-test and post-test knowledge scores of subjects.

\begin{tabular}{|c|c|c|c|c|c|c|}
\hline & Mean & $\begin{array}{c}\text { Mean } \\
\text { Difference }\end{array}$ & $\mathbf{S E}_{\mathrm{D}}$ & df & t' value & L.0.S \\
\hline Pre-test & 15.68 & \multirow[t]{2}{*}{8.22} & \multirow[t]{2}{*}{0.047} & \multirow[t]{2}{*}{59} & \multirow[t]{2}{*}{14.93} & $\begin{array}{c}\mathrm{P} \varangle 0.05 \\
\text { H.S }\end{array}$ \\
\hline Post-test & 23.90 & & & & & \\
\hline
\end{tabular}

The mean post-test knowledge scores of subjects were significantly higher than their mean pre test knowledge scores after the administration of video assisted teaching (' $t$ ' calculated value of pre-test and post test knowledge scores $=14.93, p \varangle 0.05$.). Hence the research hypothesis was accepted indicating that the video assisted teaching had been the effective method in increasing the knowledge of the subjects. There was no significant association between knowledge of Breast Crawl and selected demographic variable i.e. education and clinical experience

\section{Discussion}

Being a new research study in the area of early initiation of breast feeding, the researcher lacks exact review of effectiveness of video assisted teaching on Breast Crawl. The findings are Consistent with the experimental study conducted in Udupi district among 50 General Nursing students to determine the effectiveness of video teaching as an educational package program on management of aggressive patients. The study findings revealed that there was a significant Difference between knowledge and skill scores $[t=22.62, p \varangle 0.05]$ and also there was a Significant difference between the mean pretest and post test skill scores $[t=63.76 p<0.05]$.

\section{Conclusion}

M any health personnel in maternity services are probably 
not aware of implementing the recommendation to 'Initiate breastfeeding within half an hour of birth'. Even in those places where health professionals are well informed and keen to initiate breastfeeding within half an hour of birth, awareness of Breast Crawl is lacking .The Phenomenon is proving to be a breakthrough in overcoming commonly encountered problems in early breastfeeding. Provide the information to parents and birth attendants so they can create the quiet, calm unobtrusive environment to allow this event of the 'breast crawl' to occur. There are many benefits to using video in education as shown in several decades of research.

\section{Reference}

1. Starting the process of mother-infant bonding. - Pub Med - NCBI [Internet]. [cited $2016 \mathrm{M}$ ay 11]. Available from: http:// www.ncbi.nlm. nih.gov/pubmed/16188786

2. [Skin-to-skin contact after birth as a factor determining breastfeeding duration]. - Pub M ed - NCBI [Internet]. [cited 2016 M ay 11]. Available from: http://www.ncbi.nlm.nih.gov/pubmed/11679683

3. EARLY MOTHER-NEONATE CONTACT AND THE MOTHER-CHILD RELATIONSHIP - Lamb - 2006 - Journal of Child Psychology and Psychiatry - Wiley Online Library [Internet]. [cited 2016 May 11]. Available from: http://onlinelibrary.wiley.com/doi/10.1111/j. 14697610.1983.tb00124. $x /$ abstract? systemM essage $=$ Wiley+Online+ Library+will+be +unavailable+on+Saturday+14th +M ay+11\%3A00$14 \% 3 \mathrm{~A} 00+\mathrm{BST}+\% 2 \mathrm{~F}+06 \% 3 \mathrm{~A} 00-09 \% 3 \mathrm{~A} 00+\mathrm{EDT}+\% 2 \mathrm{~F}+18 \% 3 \mathrm{~A} 00$ $21 \% 3 \mathrm{~A} 00+\mathrm{SGT}+$ for + essential +maintenance.Apologies ffor the tinco nvenience.

4. Charlop M, Daneswer S, Christy. Television, video highly effective teaching tool for elementary to high school students. National Teacher Training Institute 2003.

5. Stirling D, Williams M K, Padget $H$. Video proves highly effective for teaching and providing positive behavior support for persons with developmental disabilities. Journal of positive behavior interventions. Arizona State University Winter 2003. 